\title{
PROBLEMS OF AGRICULTURAL AND RURAL DEVELOPMENT IN SERBIA AND NECESSITY OF NEW AGRICULTURAL POLICY ${ }^{1}$
}

\author{
Radovan Pejanovič2, Danica Glavaš - Trbič̉ ${ }^{3}$ Mirela Tomaš-Simin ${ }^{4}$
}

\begin{abstract}
Summary
The Republic of Serbia has a favorable conditions for agricultural and rural development (5,097 million ha of agricultural land, 85\% of the territory is rural). Serbia has a skilled and educated human resources and appropriate institutions for education (high schools, colleges, institutes), as well as a long agricultural tradition.

Nevertheless agriculture and villages in Serbia are in the process of decay, devastation and backwardness. Agricultural production in the period from 2000-2015 for example had positive outcome in only four years. The negative development trend was followed with de-agrarianism and demographic emptying of villages. The causes for this are numerous. The authors come to the conclusion that a new paradigm of sustainable agricultural and rural development, as well as the new agricultural policy is need.
\end{abstract}

Key words: agriculture, village, development problems, a new agricultural policy, the Republic of Serbia.

JEL: $Q 10, Q 18$

\section{Introduction}

Numerous problems of agriculture and rural areas of the Republic of Serbia can be reduced to development problems. Development problems are systemic in nature.

1 Paper is a part of research within the project III 46006 - Sustainable agriculture and rural development in the function of accomplishing strategic goals of the Republic of Serbia in the Danube Region and the project TR31095 - Production of cheese with added value manufactures from the milk from organic and sustainable systems, financed by the Ministry of Education, Science and Technological Development of Republic of Serbia. Project period 2011-2016.

2 Radovan Pejanović, PhD, Full Professor, University of Novi Sad, Faculty of Agriculture, Trg Dositeja Obradovića 8, 21000 Novi Sad, Serbia, Phone: +381 214853514 E-mail: pejanovic@polj.uns.ac.rs

3 Danica Glavaš-Trbić, MSc, Assistant, University of Novi Sad, Faculty of Agriculture, Trg Dositeja Obradovića 8, 21000 Novi Sad, Serbia, Phone: +381 214853508 E-mail: danicagt@polj.uns.ac.rs

4 Mirela Tomaš-Simin, MSc, Assistant, University of Novi Sad, Faculty of Agriculture, Trg Dositeja Obradovića 8, 21000 Novi Sad, Serbia, Phone: +381 214853514 E-mail: mirelat@ppolj.uns.ac.rs 
Economic development is a complex process with a series of successive or less successive changes. Today, it comes down to the sustainable and rural development.

The UN Agenda for sustainable development by 2020 states that economic growth and development measured only by GDP or national income is not sufficient to come to a sustainable growth and development. In addition to financial development, human development is also needed, which includes education, health care and many other aspects, including those related to agro and food production. This is also the starting hypothesis in this paper.

The current (development) problems of Serbian agriculture are complex. They can be divided into several groups: (1) problems of primary agriculture; (2) the problems arising from inadequate agricultural policy; (3) the problems arising from the lack of competitiveness of agriculture; (4) the problems of education, knowledge transfer in agriculture and the availability of new technology; (5) problems arising from current concept of (un)sustainable development, (6) the problems of the villages.

\section{Materials and methods}

Using the method of qualitative research, authors analyzed the problems and came to value judgments, which were then corroborated with qualitative indicators. Authors have used past long term research results, which have indicated in the list of used literature. The analysis included six of those groups of problems of agriculture in the Republic of Serbia.

\section{Problems of primary agriculture}

Serbia has about 5.2 million hectares of agricultural land, of which 4.2 million hectares are arable. Per capita average is 0.56 ha, which is significantly higher than in the Netherlands or Germany 5 . The problem is the irrational use of this valuable resource. Due to road construction, illegal construction and alike every year fond of arable land is decreased. It is assumed that Serbia annually loses about 25,000 ha. On the other hand, over 600,000 ha remain uncultivated. In contrast, many countries such as Netherlands and Israel are "taking" every inch of land from sea or desert and turning it into arable land.

When it comes to the land problem, the uncompleted restitution is still a big problem. Since 2000 the several law drafts on restitution have been done (the latest was adopted in 2011) but the process is not completed.

The problem is, also, the state-owned land, about 800,000 ha, which is leased (at a relatively high price through bidding), but is also irrationally and arbitrary used.

The problem is that the average farm in Serbia uses 4.5 hectares of agricultural land

5 Favorable agricultural conditions are important for so called growth based on catchingup, which is highlighted by American economist Jeffrey Sachs (The age of sustainable development, CIRSD the Official Gazette, Belgrade, 2014). 
- almost four times less than holdings in the EU. Moreover, such small farms are fragmented into smaller plots of irregular shape and far apart. If we take into account the state of roads, it is clear that this farms and plots are very difficult and expensive to cultivate, especially in hilly areas, and that it is very difficult to farmers to make a profit on domestic and international markets. The only way to overcome this problem is land consolidation - merging parcels of agricultural land.

In recent decades the primary agricultural production in Serbia was in a permanent unfavorable economic situation, which is reflected in the "price scissors", which are open at the expense of primary agricultural products, as well as the disparity of income, but also in other ways, all of which have unfavorable impact on agricultural producers (Pejanović, 2013).

Agricultural production in the period 2000-2015 achieved growth in just four years. According to the Serbian Statistical Bureau in 2015, Serbian agriculture has declined production volume by eight percent compared to 2014, instead of the planned growth of about six percent.

In the value structure of total agricultural production in Serbia plant production has a dominant share. Multi-annual average is around $67 \%$, with corn as a major product with $25 \%$ of the total value of agricultural production. Particularly disturbing is the drastic decline in livestock production, which has a share of $35.7 \%$ in realized value of agricultural production. In the more developed EU countries share of livestock ranges from 60-70 percent. It tells about the torn livestock-farming chain, without which there is no successful development of agriculture (Pejanović, 1995).

Trends in livestock production are negative in past few decades. Just in last ten years, the number of livestock units per hectare of agricultural land decreased from 0.34 to 0.27. One of the indicators of the devastation of Serbian livestock production is export of "baby biff". According to the data of the Customs Administration in 2015, Serbia exported only 315 tons of high-quality meat. How little it is can be seen from the fact that in 1990 50,000 tones of "baby biff" was exported from the former Yugoslavia, out of which 30,000 tons came from Serbia.

The problems are also present in other branches of agriculture (farming, fruit growing and viticulture). In the context of crop production there is unused potential in seed production, which is the world profitable branch of agriculture, for which Serbia has institutes, human capital and tradition, but underutilized and unorganized.

The problems of Serbian agriculture arise from unresolved issues of financing and lending. Due to the specifics of this production ("factory under the open sky"), as well as the strategic importance of food production, state support is necessary, which is insufficient in Serbia. Agricultural budget, for example, for 2016 year decreased and amounts only about $3 \%$ of the total budget (although the agriculture and food industries account for over $20 \%$ of the overall GDP). Consequently Serbian government reduced subsidies (although anything and everything is subsidized - from jobs to foreign 
investors to large loss-making state-owned enterprises). In addition, bank loans are for a long time unfavorable.

Although favorable, water regime is insufficiently exploited. Danube-Tisa-Danube canal (with $960 \mathrm{~km}$ of canal network) the largest single hydro system in the world is very little used. Of the total arable land about three per cent is irrigated or close to 100,000 ha. At the same time in the world about 17 percent of arable land is irrigated.

Problem of primary agriculture exacerbates the loss of purchasing power of the population, due to the economic and financial crisis. This has led to an increase in poverty, which is reflected in consumption fall of meat, milk, butter and fruit (Pejanović, 2010). In many EU countries consumption of these more expensive food products is higher for at least 50 percent. At the same time sales of cheaper foods (bread, rolls) has increased. The fact is that consumption of all food products in Serbia in 2015 was in decline when it is compared with the multi-annual average in the previous period ${ }^{6}$.

\section{The problems arising from inadequate agricultural policy}

Creation and implementation of Serbian agricultural policy is limited with numerous factors of systemic, economic, political, institutional, legislative nature. Exhausting and long transition (which lasts for more than a quarter of century) is followed by unsuccessful privatizations, corruption, social stratification, debts, partocratic division of power. It has had the effect of treating agriculture as a "social shock absorbers" of society, not as promising and profitable industry (Pejanović, 2014). This was particularly the case in the 90s of the last century (the "decade of Serbian catastrophe"). For the past 15 years, Serbian agriculture has led 12 ministers, always starting from the beginning, wandering, experimenting, with wrong strategic decisions, always skirting the agriculture and agro-economy, although agro-economic science and profession try to point that Serbian agriculture has a comparative advantage, tradition, knowledge and human resources. The numerous agricultural development strategies were and remain "a dead letter".

Financial constraints are chronically limiting factor for agricultural and rural development of Serbia. And not just in terms of incentives, but above all in terms of investments, which are almost ceased in this area. As for the banking assets, they were "usurious" altogether. Irrationality spending of budget incentives was no fewer problems.

Although Serbia has adopted several laws (Act on Agricultural Land - 2006, 2008, 2009; Law on Agriculture and Rural Development - 2009, 2013; Law on Incentives in Agriculture and Rural Development - 2013, 2014; Law on financing and the provision of financing agricultural production - 2014), to assist and protect farmers, its assistance

6 This is evidenced by the fact that today in Serbia only $38 \mathrm{~kg}$ of meat per capita is spent and about 44.000 tons of all kinds of meat is produced. In 1990 on the territory of today's Serbia around 650.000 tons of all kinds of meat was produced and $65 \mathrm{~kg}$ of meat per capita was consumed per year. 
and protection are insufficient for more serious development of domestic agriculture, and incentives are negligible in comparison to the incentives EU farmers receive. In addition, small producers who dominate are poorly organized, divided and unable to equally negotiate with traders and processors on the terms of sale, where the state does not even attempt to protect them from abuse in the market, as does the European Union.

As a result of all this, Serbian agriculture is unattractive for domestic and foreign investment. Of total foreign direct investment in Serbia, agriculture accounts for only 0.7 to 1.6 percent.

All this leads to lagging behind of Serbian agriculture and food industry, which profits from agriculture about two billion dollars per year, as opposed to say, Netherlands which profits out of food and agriculture industry over 70 billion dollars per year.

\section{The problems arising from the lack of competitiveness of agriculture}

When it comes to competitiveness, the key limiting factors of Serbian agriculture competitiveness are: unfavorable agrarian structure (4.5 ha average farm size) dominated by small farms - about 650,000 households (obsolete machinery); disorganization of agricultural commodity producers (associations, cooperatives, clusters, underdeveloped cooperation and contract processing, unregulated conditions of purchase and purchase prices, unregulated system of payments, high participation of middlemen etc.); lack of regulation of agricultural markets (monopolized markets, asymmetric market information, price instability, inefficient inspection bodies, lack of purchasing and distribution centers, underdeveloped commodity-exchange market, inefficient system of stockpiles) etc.; corruption (as a companion of bureaucratic, nonmarket, partocratic states dominated by monopolies - party, company, trade, especially monopolies for coercion and obligatory); inadequate role of the state (low agricultural budget, relatively low subsidies, unresolved financing and investment, underdeveloped network of advisory services, undeveloped system of recording and reporting in agriculture, lack of an integrated agricultural information system); inefficient use of land resources; relatively high price for state land lease; deagrarization and depopulation of villages (every fourth village is on the path of extinction, in $86 \%$ of villages the number of inhabitants is decreasing); the problem of food safety; climate change (which take a heavy toll by floods and droughts).

The lack of competitiveness of agriculture, agricultural producers and agricultural products in Serbia reflects in following: national agricultural production is expensive and inefficient (cost and pricing); extensiveness of the total agricultural production (0.25 livestock units per hectare, compared to 0.98 in the EU, which is a consequence of low productivity, inefficient land policy, outdated technical equipment, low level of business integration); underdevelopment and insufficient use of irrigation systems (small percentage of irrigated land); unfavorable business environment (relatively high index of business and political instability, high level of corruption, heavy administration, etc.); product quality does not sufficiently meet the EU standards (slow introduction of 
quality standards, often compromised food safety); the largest part of exported national products consist of primary agricultural products (corn, raspberries, fruit, livestock), a small share of added value (knowledge applied through technology, and marketing); agro-industrial reproduction chain has been violated and "torn" (production, processing, transport, logistics, agriculture-livestock); no unified supply and insufficient knowledge of export markets; underdevelopment of distribution phase, promotion and other marketing activities related to agricultural products; uncertain economic conditions for entrepreneurship and entrepreneurial spirit are underdeveloped (slow development of small and medium-sized enterprises in agribusiness); underdeveloped and weak system of lobbying (the agrarian lobby).

The lack of competitiveness is characterized, therefore, with unfavorable structure of exports of agricultural products, dominated by primary agricultural products, not processed products with value-added (Pejanović et al., 2005). In the structure of agriculture exports meat accounts for only about 2.7 percent. On the other hand, the import of agricultural products is high. If we analyze the basic groups of agricultural products in exports in 2014 cereals $(19.8 \%)$ dominate, followed by fruits $(17.9 \%)$, various beverages $(7.2 \%)$, tobacco and tobacco products $(5.7 \%)$, animal and vegetable fats and oils $(5.2 \%)$, miscellaneous of food products, etc.

Process of branding of Serbian agricultural products is inadequate and slow (Pejanović et al., 2009). In the EU there are 1,200 protected agricultural products. Serbia has a lot of products with brand name and geographic origin at the national level. ${ }^{7}$ However, the process of protection at EU level is quite complex and time consuming, and Serbian producers, obviously, do not see their interest in this. However, the price difference in the EU goes from 10 to 30 percent. Unsurprisingly Italy and France are the leaders in this area, they account for about 60 percent of total turnover. Only Italy has nearly 200 branded products.

\section{The problems of education, knowledge transfer and access to new technologies in agriculture}

Regarding to this a few questions arise: What is the quality of knowledge in Serbian country (especially in agriculture)? The issue refers also to the question of the quality of Serbian education. The answer to this question is not, unfortunately, positive. Knowledge in Serbia, in fact, in many areas significantly lags behind developed countries. The cause is in unfavorable economic position of Serbian science and education, resulting in declining quality. Despite the relatively low percentage of allocations for science and education in GDP (from 0.30 to 0.50 percent of GDP), which is much lower than the EU average, the reduction of salaries to teachers and assistants in educational institutions,

7 Even 52 (Užice beef prosciutto, Srem sausage, savory, tea, Kladovo caviar, Leskovac grill meat, futoški fresh and sauerkraut, pork cracklings from Valjevo, Arilje raspberries, homoljski honey, ajvar from Leskovac, Sjenica sheep cheese and lamb, Ečka carp, krivovir cheese , Požarevac sausage, Zlatar cheese, Fruška Gora linden honey ...). 
as well as uncertainty about the status of researchers - say enough themselves. Except the "white plague", this is followed by one more negativity is a serious problem in Serbia - it's "brain drain", the exodus of young, educated, talented people from the country, with increasing and accelerating flow. Serbia has about 3,500 unemployed agricultural managers, with bachelor, master and $\mathrm{PhD}$ degrees.

Inadequate is the role of the state in this area, but there is also the problem of disorganized, unregulated, uncontrolled, anarchic education market. Inflation of Universities in Serbia (10 private and 8 public universities, plus a large number of various higher education institutions) has led to the devaluation of the quality (bachelor, master and doctorate).

Transfer of knowledge in Serbia is followed by the problem of (non)functional, (non)entrepreneurial knowledge (Pejanović et al., 2013). Due to financial reasons many faculties have reduced the so-called student practice, which is a devastating for example for students of agronomy. On the other hand, in the process of transition and devastating (failed) privatization in agriculture, many agricultural enterprises disappeared in which the students of Serbian faculties successfully performed agronomic practices. Owners of many new businesses, unfortunately, have no interests or will to enter into such a form of cooperation that has multiple benefits for all. On the other hand, entrepreneurship is not enough promoted in Serbian education system, especially agrarian entrepreneurship as a new development philosophy. The problem is that at the macro level, and then at all the lower levels were not accepted ideology of the new society, of which we are, unfortunately, far away. This new ideology promote that innovation and entrepreneurship based on knowledge are the holders of economic and social development (knowledge-based society).

The transfer of knowledge and technology transfer are closely related (Pejanović et al., 2013). The problem is the slow implementation of new technologies in Serbian agribusiness. The process of technology transfer from scientific and educational institutions to the economy in Serbia is far behind compared to developed European and other countries. Institutional support to the technology transfer between universities and industry is at relatively low level. In favor of this thesis is the fact that we are at the bottom according to the number patents in Europe.

One of the new technologies in agriculture is called "Precision agriculture" or "agricultural production based on the information". Its purpose is the economical use of water, nitrogen and other inputs in order to produce food with less environmental impact. In addition, farmers in this way can save, get better revenue and reduce waste of resources.

\section{Problems arising from the (former) present concept of (un)sustainable development}

Modern food production is based on input-intensive agriculture, which means that to a large extent depends on fertilizers, pesticides, irrigation and mechanization. On other hand, all this depends on the energy of fossil fuels. Considering the impact of agriculture on the 
environment an American professor Jonathan M. Harris points out the following negative effects: erosion and soil degradation; the use of fertilizers; use of pesticides; irrigation and inefficient use of water; GM foods as controversial technologies (Haris, 2006).

A serious problem is food safety. For example, there is a case of pork meat or forbidden transport of eggs through the territory of the EU, because we did not agree on the control of salmonella with European regulations. Serbia is, in fact, the only country in the region that does not mark the eggs and which due to non-compliance with EU veterinary legislation does not permit the export of eggs in the EU. The danger is biological, chemical and physical substances in food, or condition of food that can cause adverse effects on human health (Havranek et al., 2015). We should use biologics, as an alternative to chemical protection. It should also work on education and stricter control.

Just as we need to find a new energy path based on energy efficiency and fuels with low carbon content, it will be necessary to find new farming systems, which will inflict less damage to the environment and that will be ecologically sensible and sustainable.

The energy sector of Serbia expresses the high dependence on imported energy sources with low energy efficiency, both in production and in consumption. There is a low share of renewable energy sources, although Serbia has a large quantity of biomass. Energy production processing of biomass is an area that represents a significant potential of Serbia, especially AP Vojvodina, due to the fact that it is an agricultural area with large quantities of plant, primarily crop residues. In addition, Serbia is creating over 270 thousand tons of animal waste, of which only about $20 \%$ is used, which indicates the extent of pollution. Negative effects on the environment have burning of crop residues, which in Vojvodina cornfields reaches up to $60 \%$. To do this, they is a big loss of organic matter, humus destroyed, and carbon, nitrogen and sulfur go into the atmosphere, which are important elements for the growth of crops.

Agriculture is highly exposed to the negative effects of climate change. Droughts and floods are the side effects of this global world phenomenon, which largely pays tribute in Serbia (Njegomir et al., 2016). According to estimates of the Ministry of Agriculture and Environmental Protection since 2000 that damage in Serbia amounts to more than five billion euros. In that ensures only eight percentages of the surface and estates.

\section{The problems of Serbian villages}

The results of the Census in the Republic of Serbia in 2011 showed that the demographic trends are unfavorable especially in rural areas. Of about 5,965 so-called other settlements, which are automatically considered as rural, about 1,200 are in the process of disappearing. This means that 15 percent of the villages are empty and in about a thousand villages have less than a hundred inhabitants. From 1991 to 2012 Vojvodina has lost 110,000 inhabitants, Šumadija and Western Serbia 180,000 and southern and eastern Serbia lost more than 200,000 people. The forecast is that by 2050 there will be 500,000 fewer people and a quarter of the population will be older than 65 years. 
Table 1. Villages in Serbia*

\begin{tabular}{|c|c|c|}
\hline Population & Number of villages & Share (\%) \\
\hline $0-49$ & 535 & 11.8 \\
\hline $50-99$ & 460 & 10.1 \\
\hline $100-199$ & 692 & 15.2 \\
\hline $200-399$ & 922 & 20.3 \\
\hline $400-599$ & 583 & 12.8 \\
\hline $600-799$ & 342 & 7.5 \\
\hline $800-999$ & 253 & 5.6 \\
\hline $1,000-1,999$ & 475 & 10.5 \\
\hline $2,000-3,999$ & 201 & 4.4 \\
\hline $4,000-5,999$ & 42 & 0.9 \\
\hline $6,000-7,999$ & 23 & 0.5 \\
\hline 8,000 and more & 13 & 0.3 \\
\hline Before Census in 2011 & 4,541 & 100 \\
\hline
\end{tabular}

Source: RIS, 2011.

Note: *Serbia without KM, Census in 2011. For municipalities Preševo, Bujanovac i Medveđa the data were taken from 2002.

The birthrate in Serbia is below the simple reproduction of the nation. The birthrate in Central Serbia is 1.41 , or 1.38 in Vojvodina. In Serbia every year approximately 35,000 to 40,000 people more die than it was born. In the region only B\&H is under the Serbia. The predominance of the number of deaths over births is far bigger reason for the depopulation of villages, then migration itself.

Dramatically accelerates the reduction of the population in small communities. The last Census showed that the number of vacant houses drastic increases in the municipalities east, southeast Serbia and Banat. In addition, Serbia is among the 10 countries of the world with the oldest population, and in eighth place after poverty (Eurostat, 2015). According to RIS, average pension of Serbian farmers is 10,600 dinars (less than 100 euros).

Therefore, the image of Serbian villages is negative. This is proved by the following data, the results of the last Census: in 1,034 settlements in Serbia is less than 100 inhabitants; in 550 settlements is less than 50 inhabitants; in 86 percent of the villages population is decreasing; in Serbia 73 percent of the villages have no institution of culture or library; in Serbia is now about 50 empty settlements, while 85 of them have fewer than ten residents; there is about 50,000 empty houses and on another 150,000 is written that in them now no one lives; about 2,000 villages have no post; 173 primary schools have just one student; 500 villages have no asphalt road or connection with the world; 400 villages have no shops; 2,760 villages have no kindergartens; in 230 villages have no primary school; two-thirds of the villages have no ambulance.

And finally, in Serbia today has more than 200 villages without population younger than 20 years and more than half of the country's population lives in the countryside. In the last 10 years, even 370 rural settlements of Serbia have not given one baby. 
So difficult living conditions, distance from cities, poor road network and almost no chance of making money besides agriculture are the most common reasons in recent decades for the devastation of villages (Pejanović, 2015). It is forgotten that they are not just for food production, but also its citizens must have a decent life. For example, in Slovenia if there are five houses and few people live in them, produce something, associated in cooperatives, it is known what and for whom they are producing. In contrast, in Serbia between 600,000 and 800,000 hectares of arable land is not used and they are mainly located in border areas. The devastation of Vojvodina villages is most notable in the southern Banat and municipalities Plandište, Alibunar and Bela Crkva.

We can conclude that it is a tragedy of Serbian villages. And tragedy of Serbian villages is actually a tragedy of Serbian people.

\section{Instead of a conclusion: the necessity of a new agricultural policy}

As can be seen from the above, the current development problems of agriculture in Serbia are numerous. The causes for this are systemic and global nature and range of the unfavorable economic situation of agriculture in the current concept of socioeconomic development, to inadequate agricultural policies, inadequate role of market, government and other institutions, disorganization of commodity producers, irrationality and inefficiency at all stages of reproduction, economic and environmental crisis and climate changes, as well as a number of other causes that are the limiting factors of converting comparative into competitive advantages.

When it comes to the village it is about his decay and "putting out" due to reclamation, low fertility, a long and unsuccessful transition and devastating privatization, regional backwardness and a number of other causes of the economic, political, social, demographic and environmental nature.

Logical conclusion is: to speed up agrarian and rural development of Serbia, to keep the population (who for decades is rapidly leaving villages) and employ them (especially the young and educated) in almost abandoned villages, it is needed significantly higher investments in agricultural development. Measures of agrarian policy should stimulate faster development of animal husbandry, to increase its share in the value of agricultural production, to encourage farm agribusiness, agrarian entrepreneurship and export programs. In addition, the need to increase salaries and pensions in order to increase the purchasing power of the population. In order to increase the investments it is necessary to stimulate strategic partnership, modeled as in Romania for example, which implements the strategic partnership with China at 700,000 hectares of its own land in agricultural production and scientific research in the field of biotechnology. Investments in China are involved also in agriculture of the Ukraine.

In the process of European integration, on this long and "thorny" way, we need systemic changes, structural reforms, "transition in our heads", even change in the national culture ("social genotype") in many areas. 
The institutional changes that are necessary in the process include strengthening existing and building new agrarian institutions, such as the agrarian chamber, the cooperative sector, NGOs, agricultural universities, etc. Also, it is needed specialized agencies such as the IPARD Agency, Paying Agency for Agriculture and Agency for market intervention. In addition, it is necessary to establish a system of accounting indicators from farms as well as the integrated administrative control system of payment, all modeled on the EU example. It is necessary to formulate a unified inventory and Fund of agricultural land, in order to have knowledge of Serbian land resources, especially since September 1, 2017 shall come into force provision of Agreement on the Stabilization and Association, according to which foreigners are entitled to the unrestricted purchase of Serbian land. The establishment of these institutions will stabilize the market of agricultural products (work of the Agency for market intervention) (Jovanović et al., 2017), there will be necessary to increase the volume of investment in domestic agriculture and rural development (IPARD Agency work), will be created much-needed analytical basis for the creation of an adequate agricultural policy.

The weaknesses of Serbian system of assistance and protection to farmers Serbia will have to remove, which is one of the conditions in the negotiation process with the EU. It would be desirable also that Serbia legally regulate agricultural organizations and thus to encourage the association of farmers in them. In that way, they would strengthen its position in the market.

Thus, policy of agricultural incentives and rural development policy include changes, primarily agrarian policy change, on the one hand, and institutional changes, on the other hand. These changes should shift the trajectory of development. From extensive, uncompetitive production should move to an intense, competitive production. Otherwise, Serbia will instead to be the exporter, become importer of food, what warns us the World Food Organization - FAO. It is necessary, for example, to create and implement a development concept of regionalization and regionalization at the level of Serbia (lowland, mountain and hill-mountain region), which would increase the competitiveness of Serbian agriculture.

Further progress of agricultural development is impossible without new knowledge and innovations in technology tillage (environmental technology), production of health - safe food, networking and association of producers, modernization and improvement of food marketing. Investments in knowledge and science must be significantly bigger, as well as technical - technological solutions.

Renewable energy resources can be considered as an important factor in the fight against the reduction of energy dependence, as well as way of reducing emissions of greenhouse gases (especially carbon dioxide). Previous studies, however, show that in Serbian production costs are higher than the prices of energy products on the market, which calls into question the economic justification of investment in these plants. Therefore, these forms of energy production, for which we have resources, must be supported by the state, through various types of incentives, allowances and subsidies. 
As regards the transfer of knowledge and technology should encourage both technological and organizational innovation in agrosector (through development of a system of scientific and educational institutions, development of cooperation between University and economy, government support to scientific research, a higher percentage of expenditures for education, science, research and development). It is necessary to connect universities, companies, local communities and other institutions and civil society organizations, with the aim of finding solutions for sustainable development. It should be supported the transfer of high technology from abroad (through imports of equipment and knowledge, direct foreign investments, purchase of licenses, leases and various senior and complex forms of cooperation between Serbian companies with foreign partners). It should be invested in the construction of a waste water treatment plant, raising the level of recycling, waste separation, as well as the construction of regional landfills.

The solution of the most important problems is in the concept of integrated rural development. This concept in EU is based on overall development of rural areas. Multifunctional agriculture is part of this concept, and it involves other than primary agriculture and rural development activities, especially tourism: eco-tourism (in protected nature zones), ethno-tourism (highlights historical and ethnological value), rural tourism and health, recreational and educational tourism. In rural areas is particularly important agro-tourism, which in combination with organic food production could be big chance. In this way, it can come to the fore economic, environmental, tourist and cultural effects of this concept.

Alternative for sustainable development is organic farming, as a controlled system of food production and as a production system that maintains the health of land, ecosystems and people. It relies on ecological processes, biodiversity and cycles adapted to local conditions. It combines tradition, innovation and science with the aim to use the shared environment and promote sustainable relationship and a healthy quality of life. It is part of sustainable development system and is based on the use of natural materials. In this way it becomes a holistic approach to agriculture, integrated system, which allows an increase in biodiversity as a necessary measure to increase productivity and protect agroecosystems. For all these reasons it is a promising resource for development of the Republic of Serbia that is very little used (only 0.28 percent of the total utilized agricultural area or 10,000 hectares in total). This sector of food production has risen in the world four times in last 12 years and there has been no decrease even in times of economic crisis.

Research and education are a necessity caused by scientific and technical progress and agrarian revolution, which take place in the new society that is coming - a knowledge society. Climate changes are growing threat to agriculture and should be prevented. Manufacturers need to implement a series of measures aimed at adaptation to climate changes. Adaptation involves the use of good agricultural practices, ensuring the application of the concept of health and food safety. Operation in the field of climate change actually operates in the sectors of waste management, protection of biodiversity, preservation of clean air, water and soil. 
What is required is a new paradigm (patterns, models) of development and behavior. It is necessary, first of all, at the macro level to adopt a national strategy of development in which agriculture, agribusiness, agro-industry should be leading branches and activities in Serbia. In this concept, rural development should be a key determinant of development. In this regard, new development philosophies are the agribusiness, agrarian entrepreneurship and multifunctional agriculture. As a result of this approach the village has the opportunity and the ability to revitalize and develop, not only as the place where the products are with good quality (integrated, organic, geographically protected), but also as a center of life (especially young farmers), labor (self-employment) and families (demographic renewal). New agricultural policy must be stable, predictable and consistent, set with the strategic development goals, previously recognized at all levels, aligned and harmonized with the EU common agricultural policy.

And finally, why is all this important? It is important because of the huge development potential of Serbia in the field of agriculture and rural areas. Quality land, human resources and tradition are factors of comparative advantage. Food, as a strategic product, the growth of the world population and demand for food are development stimulants of agriculture, agro-economy, agro-industry, agribusiness, agrarian entrepreneurship and rural development, that we need and we must take advantage of.

\section{Literature}

1. Atali, Ž., Gijom, M. (1987): Ekonomska nauka i problemi čovekove sredine antiekonomika, IEI, Beograd.

2. Ayres, V.R. (1981): Nesigurna sutrašnjica, Globus, Zagreb.

3. Climate change and food security: risk and responses, Food and Agricultural Organization of the United Nations, Rome, 2016.

4. Galbraith, J.K (1981): Doba neizvjesnosti, Stvarnost, Zagreb.

5. Gorc, A. (1982): Ekologija i politika, Prosveta, Beograd.

6. Gruhl, H. (1985): Jedna planeta je opljačkana, Prosveta, Beograd.

7. Haris, M. Dž. (2006): Ekonomija životne sredine i prirodnih resursa: savremeni pristup, Data- status, Beograd.

8. Havranek, Jasmina i saradnici (2015); Sigurnost hrane od polja do stola. M.E.P. d.o.o., Zagreb.

9. Heintz, T. (2008): Winds of Change for Agricultural Risk, Catastrophe Risk Management, Guy Carpenter.

10. Jovanović, D., Milenković, N., Damnjanović, R. (2017): Ocenjivanje i predviđanje potreba potrošača, Oditor, Vol. 3, No. 1, pp. 70-79.

11. Meadors, D. (1984): Granice rasta, Stvarnost, Zagreb.

12. Njegomir, V., Marović, B., Pejanović, R. (2016): Klimatske promene i osiguranje poljoprivrede, monografija, Naučno društvo agrarnih ekonomista Balkana, Beograd.

EP 2017 (64) 4 (1619-1633) 
13. Pejanović, R. (1995): Ekonomija i agrar, monografija, Poljoprivredni fakultet, Novi Sad.

14. Pejanović, R., Njegovan, Z. (2005): Tranzicija i agropirvreda, monografija, Poljoprivredni fakultet, Novi Sad.

15. Pejanović, R., Njegovan, Z. (2009): Preduzetnišvo i (agro)ekonomija, monografija, Poljoprivredni fakultet, Novi Sad.

16. Pejanović, R. (2010): Demografski problemi kao ograničavajući faktor ruralnog razvoja AP Vojvodine, Glasnik antropološkog društva Srbije, Antropološko društvo Srbije, Novi Sad, pp. 65-75.

17. Pejanović, R. (2013): Ogledi iz agrarne i ruralne ekonomije, monografija. Poljoprivredni fakultet, Novi Sad.

18. Pejanović, R., Tomaš-Simin, Mirela, Glavaš-Trbić, Danica (2013): Problems of Knowledge Transfer in Organic Food Production, ICTT 2013 International Conference on Technology Transfer, Book of Proceedings, University of Niš, Niš, Serbia, pp. 303-308.

19. Pejanović, R. (2014): O (ne)uspešnosti naših tranzicionih reformi, Agroekonomika, Poljoprivredni fakultet, Novi Sad, vol. 43, no. 63-64, pp. 23-38.

20. Pejanović, R., Radović, G. (2015): Education as a factor of the development of rural tourism in the Republic of Serbia, Thematic Proceedings, The Fourth International Conference "Employment, Education and Entrepreneurship" (EEE 2015), Faculty of Business Economics and Entrepreneurship, 14-16 October, Belgrade, vol. 3, pp. 142-154.

21. Pejanović, R. (2015): Neodrživost dosadašnjeg koncepta razvoja i problem bezbednosti hrane, Letopis naučnih radova, Poljorpivredni fakultet, Novi Sad, no. 1, pp. 141-152.

22. Peru, F. (1986): Za filozofiju novog razvoja, IRO Matice srpske, Evropski centar za mir i razvoj, CEKOS, Novi Sad.

23. Republic Institute for Statistics, 2011, available at http://www.rzs.rs, 


\section{PROBLEMI RAZVOJA POLJOPRIVREDE I SELA REPUBLIKE SRBIJE I NUŽNOST NOVE AGRARNE POLITIKE ${ }^{8}$}

\section{Radovan Pejanovićc, Danica Glavaš - Trbićc ${ }^{10}$, Mirela Tomaš-Simin ${ }^{11}$}

\section{Rezime}

Republika Srbija poseduje bogate uslove za razvoj poljoprivrede kao i za ruralni razvoj (5,097,000 ha poljoprivrednog zemljišta i čak 85\% teritorije je ruralno). Srbija raspolaže i sa kvalifikovanim i obrazovanim ljudskim resursima i odgovarajućim institucijama (srednjim školama, fakultetima, institutima), kao i dugom tradicijom seljačke, odnosno agrarne države.

I pored svega toga poljoprivreda $i$ selo u Srbiji su u procesu propadanja, devastacije $i$ zaostajanja. Poljoprivredna proizvodnja u periodu od 2000-2015. godine, na primer, osvarila je rast u samo četiri godine. Negativni razvojni trend je praćen deagrarizacijom $i$ demografskim pražnjenjem sela. Uzroci toga su mnogobrojni. Potrebna je nova paradigma održivog razvoja poljoprivrede i sela, kao i nova agrarna politika.

Ključne reči: poljoprivreda, selo, razvojni problemi, nova agrarna politika, Republika Srbija.

8 Rad je deo istraživanja u okviru projekta broj III 46006 pod nazivom „Održiva poljoprivreda i ruralni razvoj u funkciji ostvarivanja strateških ciljeva Republike Srbije u okviru Dunavskog regiona“ i TR31095 „Proizvodnja sira sa dodatnom vrednošću od mleka dobijenog u organskim i samoodrživim sistemima“ koje finansira Ministarstvo prosvete, nauke i tehnološkog razvoja Republike Srbije. Projektni period 2011-2016.godine.

9 Redovni profesor, dr Radovan Pejanović, Univerzitet u Novom Sadu, Poljoprivredni fakultet, Trg Dositeja Obradovića 8, 21000 Novi Sad, Srbija, tel: +38121 4853514 E-mail: pejanovic@ppolj.uns.ac.rs

10 Asistent, MSc Danica Glavaš-Trbić, Univerzitet u Novom Sadu, Poljoprivredni fakultet, Trg Dositeja Obradovića 8, 21000 Novi Sad, Srbija, tel: +38121 4853508 E-mail: danicagt@polj.uns.ac.rs

11 Asistent, MSc Mirela Tomaš Simin, Univerzitet u Novom Sadu, Poljoprivredni fakultet, Trg Dositeja Obradovića 8, 21000 Novi Sad, Srbija, tel: +38121 4853514 E-mail: mirelat@polj.uns.ac.rs

EP 2017 (64) 4 (1619-1633) 
ECONOMICS OF

AGRICULTURE

\section{CONTENT}

1. Adriana Radosavac, Desimir Knežević

ECONOMIC IMPORTANCE OF USE

OF PESTICIDES IN WHEAT PRODUCTION . . . . . . . . . . . 1323

2. Berhe Gebregewergs, Muuz Hadush

DOES CLIMATE CHANGE AFFECT PRICE OF VEGETABLES:

EVIDENCE FROM TIGRAI, NORTHERN MOST ETHIOPIA. . . . .1335

3. Grujica Vico, Aleksandra Govedarica-Lučić, Zoran Rajić, Radomir Bodiroga, Ivan Mičić, Silvija Zec Sambol, Marija Mičić

MULTI ATTRIBUTE ASSESSMENT APPROACH

IN VEGETABLE PRODUCTION . . . . . . . . . . . . . . 1355

4. Igor Trandafilović, Vesna Conić, Aleksandra Blagojević

IMPACT OF DEMOGRAPHIC FACTORS ON

ENVIRONMENTALLY CONSCIOUS PURCHASE BEHAVIOUR. . .1365

5. Imre Milán Harcsa

STUDY ON THE POTENTIAL OF SUBCONTRACT

PALINKA DISTILLATION . . . . . . . . . . . . . . 1379

6. Jelena Andrašić, Vera Mirović, Nada Milenković, Branimir Kalaš, Miloš Pjanić

IMPACT OF TAKEOVER PROCESS ON EMPLOYEES -

EVIDENCE FROM FOOD, RETAIL AND FINANCIAL SECTOR . . .1393

7. Jelena Birovljev, Danilo Đokić, Bojan Matkovski, Žana Kleut

ECONOMIC PERFORMANCES OF AGRICULTURE

OF CEFTA AND FORMER CEFTA COUNTRIES . . . . . . . . . . 1413

8. Jelena Marković, Svetlana Stevović

SUSTAINABILITY OF CHEMICAL SOIL QUALITY

IN SOUTHERN MORAVA RIVER VALLEY

IN CORELLATION WITH THE FLOODING $\ldots \ldots \ldots \ldots \ldots$ 
9. Mile Peševski, Zoran Milovančević

THE CHANGES IN THE USAGE OF AGRICULTURAL LAND

IN EASTERN REGION OF REPUBLIC OF MACEDONIA

BETWEEN $1991-2030 \ldots \ldots$. . . . . . . . . . . . . . . . . . . . . . .

10. Odjuvwuederhie Emmanuel Inoni, 'Oraye Dicta Ogisi, Felix Odemero Achoja

PROFITABILITY AND TECHNICAL EFFICIENCY IN HOMESTEAD

CATFISH PRODUCTION IN DELTA STATE, NIGERIA . . . . . . . 1449

11. Olja Munitlak - Ivanović, Jovan Zubović, Petar Mitić

RELATIONSHIP BETWEEN SUSTAINABLE DEVELOPMENT AND

GREEN ECONOMY - EMPHASIS ON GREEN FINANCE

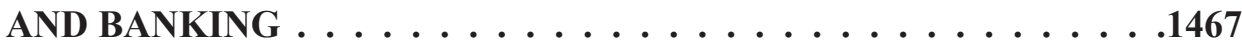

12. Petar Munćan, Dragica Božić

FARM SIZE AS A FACTOR OF EMLOYMENT AND INCOME

OF MEMBERS OF FAMILY FARMS . . . . . . . . . . . . . 1483

13. Rade Popović, Mira Kovljenić

EFFICIENCY OF WHEAT PRODUCTION ON FARMS

IN THE REPUBLIC OF SERBIA . . . . . . . . . . . . . . . . . . . . . . . . .

14. Radovan Damnjanović, Snežana Krstić, Milena Knežević, Svetislav Stanković,

Dejan Jeremić

THE DISCRIMINANT ANALYSIS APPLIED TO THE

DIFFERENTIATION OF SOIL TYPES . . . . . . . . . . . . 1513

15. Slavica Otović, Dunja Demirović, Kristina Košić, Aleksandra Vujko

FOSTERING ENTERPRENUERSHIP AT HIGH SCHOOLS:

A CASE OF RURAL AREAS IN VOJVODINA (SERBIA) . . . . . . .1523

16. Vladimir Ilić, Ivan Bauer, Anastazija Tanja Đelić, Aleksandar Nešković

INSTITUTIONAL SUPPORT FOR STRENGTHENING

ENTREPRENEURSHIP IN AGRICULTURAL PRODUCTION

OF THE REPUBLIC OF SERBIA . . . . . . . . . . . . . . . . . . . . . . . .

17. Boro Krstić, Zorica Vasiljević, Miroslav Nedeljković

INSURANCE CONTRACT AS THE BASIS FOR THE SAFETY OF

AGRICULTURAL PRODUCERS IN THE REPUBLIC OF SRPSKA • . 1555

18. Dejan Sekulić, Aleksandar Petrović, Vladimir Dimitrijević

WHO ARE WINE TOURISTS? AN EMPIRICAL INVESTIGATION

OF SEGMENTS IN SERBIAN WINE TOURISM . . . . . . . . . . . . . 
19. Milan Beslać, Ćorić Goran

FINANCIAL AND PRODUCTION ASPECTS OF GENETICALLY MODIFIED ORGANISMS $\ldots \ldots \ldots \ldots \ldots \ldots \ldots \ldots \ldots$

20. Mlađan Maksimović, Darjan Karabašević, Miodrag Brzaković, Pavle Brzaković THE EFFECTS RESULTING FROM THE APPLICATION OF THE CONCEPT OF THE SUSTAINABLE DEVELOPMENT OF RURAL TOURISM ON STARA PLANINA . . . . . . . . . . . . . . . .1595

21. Vesna Popović, Predrag Vuković, Milivoje Ćosić FOOD SAFETY AND QUALITY POLICY IN THE REPUBLIC OF SERBIA . . . . . . . . . . . . . . . . 1607

22. Radovan Pejanović, Danica Glavaš-Trbić, Mirela Tomaš-Simin PROBLEMS OF AGRICULTURAL AND RURAL DEVELOPMENT IN SERBIA AND NECESSITY OF NEW AGRICULTURAL POLICY . . . .1619

23. Saša Marković, Slavoljub Vujović, Aleksandar Damnjanović MARKETING AND HIGHER EDUCATION CONDITION IN SERBIA . . . . . . . . . . . . . . . . 1635

24. Semir Vehapi, Marina Milanović THE EFFECT OF MARKET ORIENTATION ON BUSINESS PERFORMANCE OF SERBIAN ORGANIC PRODUCERS . . . . . 1651

25. Suad Bećirović, Šemsudin Plojović, Enis Ujkanović, Senadin Plojović CHALLENGES AT STARTING AN AGRIBUSINESS IN THE HILLY MOUNTAINOUS REGIONS OF SOUTHWEST SERBIA . . . . . . . .1669

26. Vladimir Zakić, Vlado Kovačević, Jelena Damnjanović SIGNIFICANCE OF FINACIAL LITERACY FOR THE AGRICULTURAL HOLDINGS IN SERBIA . . . . . . . . . . 1687

27. Željko Bjelajac, Marijana Dukić Mijatović, Željko Vojinović PROTECTION OF LAND IN THE REPUBLIC OF SERBIA AND ECOLOGICAL SECURITY WITH REGARD TO STRATEGIC AND LEGAL FRAMEWORKS . . . . . . . . . .1703 